\title{
PENGEMBANGAN BAHAN AJAR MICRO TEACHING UNTUK MELATIH KOMPETENSI PEDAGOGIK CALON GURU
}

\author{
Satutik Rahayu'), I Gde Mertha ${ }^{2)}$ \\ ${ }^{1)}$ Program Studi Pendidikan Fisika \\ ${ }^{2)}$ Program Studi Pendidikan Biologi \\ FKIP, Universitas Mataram \\ Jalan Majapahit No. 62, Mataram \\ E-mail: satuti4977@yahoo.co.id
}

\begin{abstract}
Physics Education Student is a FKIP student who is printed to become a professional Physics teacher candidate. The competencies that must be possessed by professional teachers are pedagogic competence (ability to manage learning). As a prospective teacher who takes microteaching courses must master and have pedagogic competence. Pedagogic competence training can be done by trained eight basic teaching skills. In order for students to master the eight basic skills of teaching it is necessary to develop microteaching teaching materials. This research is a multi-year research with the type of research is development research following $4 D$ model. The purpose of this research is to develop microteaching teaching materials that have been tested the level of feasibility. Data analysis uses expert validation sheets and user responses. The result of the research shows that the teaching material of micro teaching that has been developed is in good category.
\end{abstract}

Keywords : teaching materials, microteaching, competence, pedagogic

\section{PENDAHULUAN}

Guru adalah kunci untuk membangun peradaban bangsa (Rohmadi, 2012). Oleh karena itu untuk membangun bangsa diperlukan guru yang professional. Lembaga Pendidikan Tenaga Kependidikan (LPTK) merupakan Perguruan tinggi yang menjadi tumpuan untuk mencetak tenaga-tenaga profesional dalam dunia pendidikan. Keberhasilan LPTK dalam hal ini adalah perguruan tinggi sangat menentukan mutu calon tenaga pengajar/guru untuk menghasilkan lulusan yang Terampil. Fakultas Keguruan dan Ilmu Pendidikan (FKIP) Jurusan P. MIPA Program Studi Pendidikan Fisika adalah salah satu program studi yang bertugas mencetak calon guru fisika yang kompeten dan professional. Mata kuliah pembelajaran mikro atau micro teaching adalah mata kuliah keahlian berkarya yang wajib diambil oleh mahasiswa pendidikan Fisika di semester VI sebelum mahasiswa melaksanakan PPL.
Menurut Hamalik (2009) latihan pengajaran mikro berfungsi sebagai latihan permulaan sebelum mengikuti praktek keguruan dalam kondisi yang sebenarnya di sekolah. Mata kuliah ini bertujuan membekali mahasiswa tentang keterampilan-keterampilan dasar mengajar. Delapan keterampilan dasar mengajar tersebut adalah 1) keterampilan membuka dan menutup pembelajaran, 2) keterampilan menjelaskan, 3) keterampilan bertanya (dasar, lanjut), 4) keterampilan mengadakan variasi, 5) keterampilan memberikan penguatan, 6) keterampilan mengelola kelas, 7) keterampilan membelajarkan kelompok kecil dan perorangan, 8) keterampilan memimpin diskusi kelompok kecil (Helmiati, 2013). Untuk menjadi calon guru fisika yang professional sudah seharusnya mahasiswa pendidikan fisika harus memiliki kompetensi pedagogik. Kompetensi pedagogik adalah kemampuan mengelola pembelajaran yang meliputi pemahaman terhadap peserta didik, 
perencanaan, pelaksanaan, dan evaluasi pembelajaran pengembangan peserta didik.

Mata kuliah pembelajaran mikro berisi tentang hakikat pembelajaran mikro dan delapan keterampilan dasar mengajar. Pada perkuliahan ini masing-masing mahasiswa diberikan kesempatan sebanyak 2 kali untuk tampil praktik mengajar dengan skala kecil. Setelah kegiatan praktik mengajar setiap mahasiswa diberikan kritik dan saran guna perbaikan untuk pembelajaran berikutnya. Pembelajaran micro teaching yang diperoleh mahasiswa diharapkan dapat membantu mahasiswa dalam menguasai delapan keterampilan mengajar, namun tidak sedikit mahasiswa yang kesulitan dalam menguasai keterampilan dasar mengajar.

Berdasarkan pengamatan peneliti selama mengampu mata kuliah pembelajaran mikro atau micro teaching banyak ditemukan permasalahan diantaranya adalah kurang terampilnya mahasiswa dalam menerapkan delapan keterampilan mengajar pada praktik mengajar. Kurang terampilnya mahasiswa menerapkan keterampilan dasar mengajar dalam praktik mengajar, ternyata setelah dianalisis didapatkan bahwa apa yang disampaikan oleh dosen kurang diingat oleh mahasiswa. Selain itu juga tidak adanya bahan ajar tentang delapan keterampilan mengajar sebagai referensi buku ajar untuk perkuliahan pembelajaran mikro.

Berdasarkan permasalahan di atas maka perlu dikembangkan bahan ajar micro teaching untuk membantu mahasiswa memahami delapan keterampilan dasar mengajar. Adapun tujuan dari penelitian pengembangan ini adalah untuk mengatasi permasalahan tidak tersedianya bahan ajar micro teaching di FKIP Universitas Mataram sehingga dengan dikembangkannya bahan ajar ini dapat berperan sebagai suplemen pembelajaran sarana komunikasi dosen-mahasiswa, untuk mendukung perkuliahan pembelajaran mikro atau micro teaching. Hal ini sejalan dengan pendapat Sujadi dan Sugiyarto (2010) yang menyarankan bahwa untuk bisa mendukung pelaksanaan pembelajaran mikro dengan baik, program studi harus menyediakan berbagai sumber belajar seperti buku-buku yang digunakan untuk menunjang kurikulum.

Manfaat dari penelitian ini adalah untuk menambah referensi mahasiswa dalam mengambil mata kuliah pembelajaran mikro serta menambah referensi perpustakaan FKIP Universitas Mataram

\section{METODE PENELITIAN}

Metode penelitian yang digunakan dalam penelitian ini adalah metode penelitian dan pengembangan (research and development). Penelitian pengembangan ini mengacu pada model pengembangan bahan ajar 4-D (four-D Model) yang dikemukakan oleh Thiagarajan dan Semmel dalam Trianto (2011) yang terdiri dari empat tahapan yaitu tahap pendefinisian (define), tahap perancangan (design), tahap pengembangan (develop), dan tahap penyebaran (disseminate).

Menurut Sugiyono (2013) metode R \& D merupakan metode penelitian yang digunakan untuk menghasilkan produk tertentu, dan menguji keefektifan produk tersebut. Produk yang dihasilkan dari penelitian ini adalah berupa bahan ajar microteaching yang telah teruji kelayakannya.

Trisnaningsih (2007) menyatakan bahwa pengembangan bahan ajar merupakan salah satu bentuk dari kegiatan proses pembelajaran untuk memperbaiki atau meningkatkan kualitas pembelajaran yang berlangsung. Yasa (2012) telah mengembangkan bahan ajar online mata kuliah micro teaching, hasil yang diperoleh menunjukkan bahwa bahan ajar online sudah teruji kelayakan, keunggulan, dan dapat 
digunakan sebagai suplemen pada proses belajar dan pembelajaran mata kuliah micro teaching. Dalam proses pembelajaran, bahan ajar sangat penting bagi mahasiswa maupun dosen. Prastowo dalam Niswa (2012) menjelaskan bahwa ada beberapa langkah yang harus dilakukan dalam pengembangan suatu bahan ajar yaitu analisis kebutuhan bahan ajar, menyusun peta bahan ajar, dan mengembangkan bahan ajar berdasarkan struktur dan bentuk materi yang dikembangkan.

Langkah-langkah pengembangan bahan ajar :

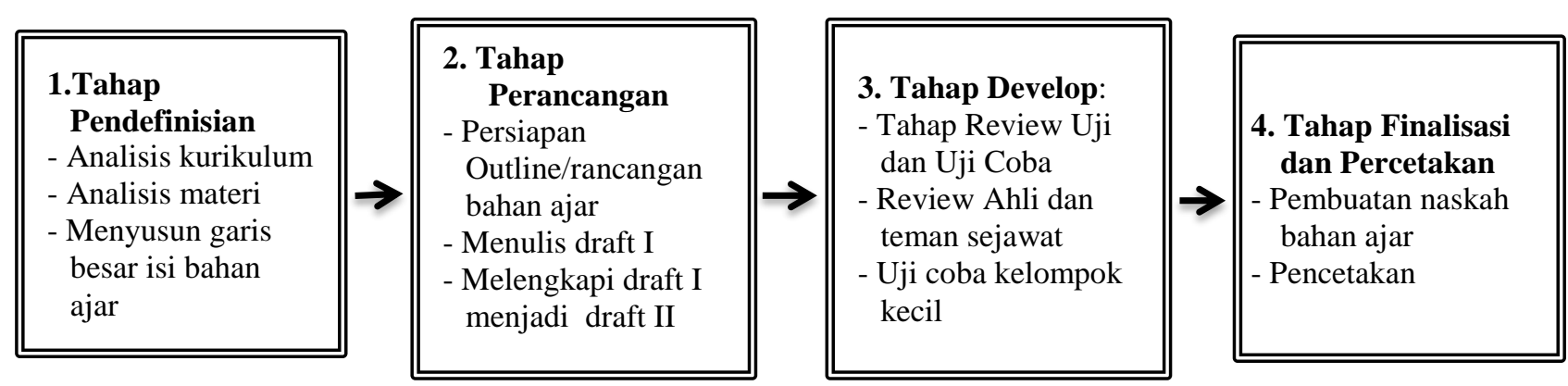

Gambar 1. Langkah-Langkah Penyusunan Bahan Ajar

Uji Coba Produk bahan ajar ini dilakukan dalam tiga tahapan dalam Uji Coba Produk, yaitu: (1) Uji Ahli atau validasi. Pada tahap ini ahli bidang studi, ahli multimedia dan ahli bahasa kemudian dilakukan analisis konseptual dan Revisi I, (2) Uji Coba Kelompok Kecil, akan dilakukan uji terbatas terhadap kelompok kecil sebanyak 10 mahasiswa sebagai pengguna produk, kemudian dilakukan Revisi II, dan (3) Uji Lapangan. Uji lapangan dilakukan pada tahun kedua setelah bahan ajar tercetak dan berISBN. Teknik pengumpulan data dengan menggunakan lembar validasi ahli dan respon pengguna. Analisis data yang diperoleh dari validator bersifat deskriptif yang berupa saran dan komentar. Rumus yang digunakan untuk menghitung persentase dari masing- masing subjek menurut Tegeh dan Kirna (2010) dalam Lorenso (2015) adalah

$$
\text { Prosentase }=\frac{(\text { jawaban } \times \text { bobot tiap pilihan })}{n \times \text { bobot tertinggi }} \times 100 \%
$$

Tabel 1. Konversi PAP Tingkat Pencapaian dengan Skala 5

\begin{tabular}{ll}
\hline Tingkat Pencapaian (\%) & Kualifikasi \\
\hline $90-100$ & Sangat baik \\
$75-89$ & Baik \\
\hline
\end{tabular}

\begin{tabular}{ll}
\hline Tingkat Pencapaian (\%) & Kualifikasi \\
\hline $65-74$ & Cukup \\
$55-64$ & Kurang \\
$0-54$ & Sangat Kurang \\
\hline
\end{tabular}

Indikator keberhasilan pengembangan bahan ajar yaitu bahan ajar dikatakan berkualitas baik jika memenuhi 3 kriteria yaitu 1) kevalidan, 2) kepraktisan dan 3) keefektifan ((Nieveen, 1999). Pada penelitian ini dibatasi hanya pada kevalidan saja, karena penelitian ini multi tahun sehingga untuk uji kepraktisan dan keefektifannya dilakukan pada tahun kedua. Bahan ajar layak digunakan jika berada pada kategori baik.

\section{HASIL DAN PEMBAHASAN}

Analisis tinjuan ahli atau pakar digunakan untuk mengumpulkan pendapat para pakar terkait instrument yang telah dikembangkan yaitu berupa bahan ajar micro teaching. Pendapat beberapa ahli ini dikumpulkan dengan menggunakan lembar evaluasi bahan ajar untuk ahli media, lembar evaluasi bahan ajar untuk ahli bahasa dan lembar evaluasi bahan ajar untuk ahli materi. Pendapat para ahli ini dikumpulkan dengan menggunakan kuesioner yang berisi 
pertanyaan, yang harus dijawab dengan dua cara, yaitu: pertama dengan memilih salah satu diantara lima option yang menunjukkan sangat baik, baik, cukup baik, kurang baik,dan tidak baik

Tabel 2. Angket Hasil Validasi Ahli Materi

\begin{tabular}{|c|c|c|c|}
\hline No & Indikator & Butir Penilaian & Prosentase \\
\hline \multirow[t]{3}{*}{1} & Kesesuaian Materi dengan & Kelengkapan materi & \multirow{3}{*}{$80 \%$} \\
\hline & Kompetensi & Keluasan Materi & \\
\hline & & Kedalaman Materi & \\
\hline \multirow[t]{5}{*}{2} & Keakuratan Materi & Keakuratan Konsep dan definisi & \multirow{5}{*}{$76 \%$} \\
\hline & & Keakuratan fakta dan data & \\
\hline & & Keakuratann contoh & \\
\hline & & Keakuratan soal & \\
\hline & & Keakuratan notasi, symbol & \\
\hline \multirow[t]{5}{*}{3} & Pendukung Materi & Penalaran & \multirow{5}{*}{$84 \%$} \\
\hline & pembelajaran & Keterkaitan & \\
\hline & & Komunikasi (Whrite and Talk) & \\
\hline & & Penerapan & \\
\hline & & Kemenarikan Materi & \\
\hline \multirow[t]{6}{*}{4} & Kemutakhiran materi & Kesesuaian materi dengan & \multirow{4}{*}{$88 \%$} \\
\hline & & perkembangan ilmu & \\
\hline & & Menggunakan contoh kasus & \\
\hline & & Kemutakhiran pustaka & \\
\hline & \multirow{2}{*}{\multicolumn{2}{|c|}{ Bahan ajar dalam kategori baik dari segi materi }} & $82 \%$ \\
\hline & & & \\
\hline
\end{tabular}

Berdasarkan tabel di atas dapat disimpulkan bahwa bahan ajar yang telah dikembangkan berdasarkan penilaian ahli materi dalam kategori baik dan layak untuk digunakan dengan beberapa saran diantaranya harus menambahkan contoh dalam pembelajaran fisikanya untuk keterampilan membuka pembelajaran dan menutup pembelajaran. Apersepsi dan motivasi pada kegiatan pembukaan lebih baik jika dikaitkan dengan pembelajaran fisika bukan hanya sebuah teori. Lembar penilaian lebih baik diletakkan pada akhir bab secara keseluruhan, karena untuk penilaian kegiatan praktik mengajar pada pertemuan berikutnya. Sedangkan untuk penilaian ahli media diperoleh hasil pada Tabel 3.

Tabel 3. Angket Hasil Validasi Ahli Media

\begin{tabular}{|c|c|c|c|}
\hline No & Indikator & Butir Penilaian & Prosentase \\
\hline 1 & Teknik Penyajian & $\begin{array}{l}\text { Kosistensi sistematika dalam penyajian } \\
\text { Keruntutan dalam penyajian }\end{array}$ & $80 \%$ \\
\hline 2 & Pendukung penyajian & $\begin{array}{l}\text { Contoh dalam setiap kegiatan pembelajaran } \\
\text { Soal latihan pada setiap akhir pembelajaran } \\
\text { Rangkuman }\end{array}$ & $75 \%$ \\
\hline 3 & $\begin{array}{l}\text { Kelengkapan } \\
\text { penyajian }\end{array}$ & $\begin{array}{l}\text { Bagian pendahuluan } \\
\text { Bagian isi } \\
\text { Bagian penyudah }\end{array}$ & $80 \%$ \\
\hline & & Rata-rata & $78.3 \%$ \\
\hline
\end{tabular}

Berdasarkan hasil penilaian validasi ahli media diperoleh bahwa teknik penyajian , pendukung penyajian dan kelengkapan penyajian bahan ajar pada kategori baik. Tetapi terdapat beberapa masukkan dari ahli media terkait bahan ajar yang telah dikembangkan 
diantaranya 1) sebaiknya daftar isi tidak dibuat secara manual tetapi menggunakan cara otomatis pembuatan daftar isi sehingga tidak akan merubah halaman ketika ada penambahan materi. Pada bagian awal bab harus di lengkapi juga analisis masing-masing kompetensi akhirnya. Dalam proses pembelajaran, penyajian bahan ajar menjadi kompetensi utama seorang guru dalam mendesain aktivitas dan kemampuan berpikir seperti apa yang harus dikuasai siswa (Dick \& Carrey, 1990). Spillane et.al. dalam Susilawati (2014) menyatakan bahwa bahan ajar harus disajikan untuk membantu siswa dalam mencari pengalaman belajar secara mandiri. Penyajian bahan ajar dengan teknik penyajian, pendukung penyajian dan kelengkapan penyajian yang baik, mahasiswa dapat dengan mudah memahami isi bahan ajar.

Tabel 4. Angket Hasil Validasi Ahli Bahasa

\begin{tabular}{cllc}
\hline No & Indikator & Butir Penilaian & Prosentase \\
\hline 1 & Lugas & $\begin{array}{l}\text { Ketepatan struktur kalimat } \\
\text { Keefektifan kalimat } \\
\text { Kebakuan Istilah }\end{array}$ & $73.3 \%$ \\
& & $\begin{array}{l}\text { Keterbacaan pesan } \\
\text { Ketepatan penggunaan bahasa }\end{array}$ & $70 \%$ \\
2 & Komunikatif & $\begin{array}{l}\text { Kemampuan memotivasi pesan atau informasi } \\
\text { Kemampuan berfikir kritis }\end{array}$ & $80 \%$ \\
3 & $\begin{array}{l}\text { Dialogis dan } \\
\text { interaktif }\end{array}$ & $\begin{array}{l}\text { Kesesuaian dengan tingkat intelektual } \\
\text { mahasiswa }\end{array}$ & $70 \%$ \\
4 & $\begin{array}{l}\text { Kesesuaian } \\
\text { tingkat } \\
\text { perkembangan } \\
\text { peserta didik }\end{array}$ & $\begin{array}{l}\text { Kesesuaian dengan tingkat perkembangan } \\
\text { emosional Mahasiswa }\end{array}$ & \\
5 & $\begin{array}{l}\text { Keruntutan dan } \\
\text { keterpaduan alur }\end{array}$ & $\begin{array}{l}\text { Keruntutan dan keterpaduan antar kegiatan } \\
\text { belajar }\end{array}$ & $90 \%$ \\
& Keruntutan dan keterpaduan antar paragraph & \\
6 & $\begin{array}{l}\text { Penggunaan } \\
\text { istilah dan } \\
\text { simbol }\end{array}$ & $\begin{array}{l}\text { Kosistensi penggunaan istilah } \\
\text { Konsistensi dalam penggunaan simbol }\end{array}$ & $70 \%$ \\
\hline
\end{tabular}

Berdasarkan hasil rekapitulasi rata-rata penilaian oleh ahli bahasa diperoleh $75.6 \%$ ini berarti bahasa yang digunakan dalam penyusunan bahan ajar berada pada kategori baik. Sedangkan untuk uji kelompok kecil dengan responden 10 mahasiswa yang sedang menempuh mata kuliah pengajaran mikro diperoleh hasil $83.3 \%$ yang berarti bahwa bahan ajar pembelajaran mikro yang telah dikembangkan dalam kategori baik dan layak untuk digunakan. Gunada et.al. (2015) menyatakan bahwa bahan ajar adalah segala bentuk bahan yang digunakan untuk membantu guru dalam melaksanakan kegiatan pembelajaran. Bahan ajar merupakan media pembelajaran. Suranti et.al. (2016) menyatakan bahwa media pembelajaran dapat membangkitkan motivasi peserta didik untuk belajar dan sangat membantu keefektifan proses pembelajaran.

Bahan ajar yang telah dikembangkan diharapkan bermanfaat bagi mahasiswa dalam pembelajaran micro teaching. Ralph (2014) menyatakan bahwa pembelajaran micro teaching sangat efektif bagi mahasiswa (guru pemula) untuk meningkatkan kompetensi 
mengajar (pedagogik) serta kepercayaan diri mereka. Kompetensi pedagogie dapat dilatihkan dengan terlebih dahulu mahasiswa mempelajari bahan ajar, dimana mahasiswa dapat memahami terlebih dahulu delapan keterampilan dasar mengajar yang ada di dalam buku ajar tersebut. Hal ini diperkuat oleh penelitian Sanusi et.al. (2016) yang menyatakan bahwa bahan Ajar Micro teaching yang telah dikembangkan efektif untuk melatihkan kompetensi pedagogik yang mengintegrasikan TIK dan nilai-nilai karakter. Efektifitas pembelajaran dengan menggunakan modul micro teaching juga telah diteliti Ambarwati et.al. (2014), dimana hasil penelitiannya menunjukkan bahwa modul ajar mikro berbasis instructional approach efektif meningkatkan keterampilan mengajar mahasiswa. Hal ini sejalan dengan pendapat Harjanto dalam Susilawati \& Khairi (2014) yang menyatakan bahwa ada beberapa asumsi tentang arti penting kedudukan bahan ajar khususnya rancangan pembelajaran yaitu dapat membantu belajar secara perorangan, memberikan keleluasaan penyiapan pembelajaran jangka pendek dan jangka panjang, rancangan bahan ajar yang sistematis memberikan pengaruh yang besar bagi perkembangan sumber daya manusia secara perorangan, memudahkan pengelolaan proses belajar mengajar secara sistematis serta dapat memudahkan belajar.

Hal ini didukung oleh hasil penelitian Susantini et.al. (2014) yang menyatakan bahwa hasil pengembangan bahan ajar micro teaching yang benar dapat diimplementasikan dalam pembelajaran micro teaching. Oktaviani et.al. (2017) menyatakan bahwa penggunaan bahan ajar juga dapat meningkatkan penguasaan konsep. Apriana dan Husni (2015) menyatakan bahwa penggunaan bahan ajar mikro dapat meningkatan produktivitas pengajaran, dimana mahasiswa dapat lebih menguasai pesan, melatih kemandirian dalam mengaplikasikan keterampilan dasar mengajar.

Dalam membentuk karakter guru yang berkompetensi tinggi, melalui pembelajaran mikro calon guru harus diberikan bekal sejak dini agar ketika berada dilapangan, guru bisa secara luwes menghadapi berbagai kendala dilapangan (Zunaidah, 2016).

\section{PENUTUP}

Berdasarkan hasil penelitian diperoleh bahwa bahan ajar micro teaching yang telah dikembangkan berada pada kategori baik dan layak digunakan dengan prosentasi penilaian oleh ahli materi sebesar $82 \%$, ahli media sebesar 78,3\%, ahli bahasa sebesar 75,6\% serta hasil angket uji kelompok kecil sebesar $83,3 \%$. Artinya buku ajar yang telah dikembangkan dapat disebarluaskan sebagai suplemen pembelajaran mikro untuk melatih kompetensi pedagogik calon guru.

\section{REFERENSI}

Apriana, D. \& Husni, M. 2015. Pengembangan Bahan Ajar dengan Cybernetics Behavior Pada Direct Instruction untuk Pengajaran Mikro di PGSD STKIP Hamzanwadi Selong 2014. Jurnal Education. 10(1), 1-14.

Ambarwati, R., Arifin, S., Sari, D.R. 2014. Pengembangan Modul Pembelajaran Mikro berbasis Intructional Approach. Jurnal LPPM. 2(2), 63-69.

Dick, W. \& Carey, L. 1990. The Systematic Design of Instructional. Third Edition. USA: Harper Collins Publisher.

Gunada, I.W., Saidu, H. \& Sutrio. 2015. Pengembangan Perangkan Pembelajaran Fisika berbasis Masalah Untuk Meningkatkan Hasil Belajar dan Sikap Ilmiah Mahasiswa. Jurnal Pendidikan Fisika dan Teknologi. 1(1), 38-46. 
Hamalik, O. 2009. Pendidikan Guru. Jakarta: PT Bumi Aksara.

Helmiati. 2014. Micro Teaching Melatih Keterampilan Dasar Mengajar. Yogyakarta: Aswaja Pressindo.

Lorenso, I.K.T.A, Swatra, I.G, Suartama I.K. 2015. Pengembangan Video Pembelajaran Keterampilan Membuka dan Menutup Serta Menjelaskan Pembelajaran Pada Mata Kuliah Micro Teaching. e-Journal Edutech Universitas Pendidikan Ganesha Jurusan Teknologi Pendidikan. 3(1), 1-12.

Neiveen, N. 1999. Prototiping to Reach Product Quality." Dalam Design Approaches and Tools in Education and Training. (Yan van Akker, Robert Maribe Branch, Kent Gustafson, Nienke Neiveen, Tjeerd Plomp) Dordrecht: Kluwer Academic Publisher

Niswa, A. 2012. Pengembangan Bahan Ajar Mendengarkan Berbasis Video Interaktif Bermedia Flash Kelas VII D SMP Negeri Kedamen. Jurnal Bahasa dan Sastra Indonesia. 1(1), 1-16.

Oktavian, W., Gunawan \& Sutrio. 2017. Pengembangan Bahan Ajar Fisika Kontekstual Untuk Meningkatkan Penguasaan Konsep Siswa. Jurnal Pendidikan Fisika dan Teknologi. 3(1), 1-7.

Ralph, E.G. 2014. The Effectiveness of Microteaching: Five Years' Findings. International Journal of Humanities Social Sciences and Education (IJHSSE) 1(7), 17-28.

Rohmadi, M. 2012. Menjadi Guru Profesional \& Berkarakter untuk membangun Insan Kreatif dan Berbudaya. Surakarta: Yuma Pustaka.

Sanusi, Murtafiah, W. \& Krisdiana I. 2016. Pengembangan Bahan Ajar Micro teaching untuk Melatihkan Kompetensi Pedagogik yang mengintegrasikan TIK dan Nilai-Nilai Karakter. Jurnal LPPM 4(1), 34-45.
Sugiyono. 2013. Metode Penelitian Kuantitatif, Kualitatif dan $R \& D$. Bandung: Alfabeta.

Sujadi, I. \& Sugiarto, B. 2010. Pengembangan Bahan Ajar Pengajaran Mikro Matematika Kelas SBI. Jurnal Matematika Kreatif-Inovatif. 1(1), 1-10.

Suranti, N.M.Y., Gunawan, \& Sahidu, H. 2016. Pengaruh Model Project Based Learning Berbantuan Media Virtual Terhadap Penguasaan Konsep Peserta didik pada Materi Alat-alat Optik. Jurnal Pendidikan Fisika dan Teknologi. 2(2), 73-79.

Susantini, A. Kholiq, A, Yonata, B, A, Maulida, A \& Faizah, U. 2014. Development Microteaching Handbook for Lecturer, Student, and Learning Laboratory Crew of Science and Mathematic Faculty. International Journal of Education. 6(3), 229-236.

Susilawati. 2014. Pengembangan Bahan Ajar Fisika Bermuatan Lifeskill untuk Siswa SMA. Jurnal Fisika Indonesia. 18(54), 86-89.

Trisnaningsih. 2007. Pengembangan Bahan ajar Untuk Meningkatkan Pemahaman Materi Mata Kuliah Demografi Teknik. Jurnal Ekonomi \& Pendidikan. 4(2), 113.

Trianto. 2011. Model Pembelajaran Terpadu: Konsep, Strategi, dan Implementasinya dalam Kurikulum Tingkat Satuan Pendidikan (KTSP). Jakarta: Bumi Aksara.

Yasa, G.A.A.S. 2012. Pengembangan Bahan Ajar Online Mata Kuliah Micro Teaching dengan Model Borg \& Gall pada Program S1 Pendidikan Bahasa Inggris STKIP Agama Hindu Singaraja. Jurnal Penelitian Pasca Sarjana Undhiksa. 1(1), 1-16.

Zunaidah, F.N. 2016. Meningkatkan Kompetensi Calon Guru melalui Kegiatan Microteaching berbasis Lesson Study (LS) Mahasiswa Pendidikan Biologi. Jurnal Efektor. (28), 21-24. 